\title{
Cuantificación de la emergencia y distribución de individuos en Melipona colimana (Hymenoptera: Meliponini) en clima templado
}

\section{Quantification of brood emergence and distribution of individuals in Melipona colimana (Hymenoptera: Meliponini) in temperate climate}

\author{
José Octavio Macías-Macíasa, J. Javier G. Quezada-Euánb
}

\begin{abstract}
RESUMEN
Melipona colimana es una abeja sin aguijón endémica de México que habita las regiones de clima templado del sur del estado de Jalisco. Se hicieron observaciones durante el otoño para contabilizar la emergencia de los individuos e inferir la posible participación de las obreras en la producción de machos. Se analizó el comportamiento de las obreras y la reina en el proceso de aprovisionamiento y oviposición (POP), se obtuvo la proporción de individuos en los panales de cría y su distribución espacial para detectar aglomeraciones de machos. En los análisis de los POP no se observaron evidencias de la actividad de obreras reproductivas. En los panales, el $65.9 \%$ de los individuos que emergieron fueron obreras, el $\mathbf{2 2 . 4} \%$ machos (sin registrarse aglomeraciones) y el $\mathbf{1 1 . 5} \%$ resultaron reinas vírgenes. Se observó que la producción de individuos sexuados (machos y reinas) fue más alta que las especies tropicales, lo que pudiera ser una estrategia de esta especie para garantizar su reproducción en climas templados. El no tener evidencias visuales de la actividad de obreras reproductivas, junto con el hecho de que no se registraron aglomeraciones de machos en los panales de cría, sugiere que en esta especie y en esta temporada del año todos los huevos que se desarrollaron como machos provienen de la reina. Con los resultados de este trabajo se amplía el conocimiento de la biología particular de esta especie de clima templado y se hace una comparación con las especies de distribución tropical.
\end{abstract}

PALABRAS CLAVE: Melipona colimana, Emergencia, Machos, Obreras, Reinas, Clima templado.

\begin{abstract}
Melipona colimana is a stingless bee endemic of Mexico that inhabiting temperate regions of the Southern State of Jalisco. Observations were made during the fall to infer the possible participation of the workers in the production of males. The behavior of workers and queen in provisioning and oviposition process (POP) was analyzed, the proportion of individuals was obtained in the brood combs and their spatial distribution for detecting clusters of males. In the analysis of POPs no evidence of reproductive labor activity of workers were observed. In the brood combs, $65.9 \%$ of individuals that emerged were workers, $22.4 \%$ males (without registering agglomerations) and $11.5 \%$ were gynes. It was observed that the production of sexed individuals (males and gynes) was higher than tropical species, which could be a strategy of this species to ensure their reproduction in temperate climates. Having no visual evidence of the activity of reproductive workers together with the fact that no clusters of males in the brood combs were found, suggests that in this species at this time of year, all the eggs that developed as males come from the queen. With the results of this study, knowledge of the particular biology of this mountain stingless bee species is extended and a comparison with tropical species is made.
\end{abstract}

KEY WORDS: Melipona colimana, Emergency, Males, Workers, Gynes, Temperate climate.

Recibido el 5 de marzo de 2014. Aceptado el 12 de septiembre de 2014.

a Universidad de Guadalajara. Departamento de Desarrollo Regional. Centro Universitario del Sur. Av. Enrique Arreola Silva no. 883. Cd. Guzmán, Jalisco. México. joseoc@cusur.udg.mx. Correspondencia al primer autor.

b Departamento de Apicultura. Centro de Ciencias Biológicas y Agropecuarias. Universidad Autónoma de Yucatán. México. 
De manera general, el conocimiento de la biología de abejas sin aguijón en clima tropical ha sido estudiado $(1,2,3)$. Sin embargo, estudios sobre la biología de meliponinos en clima templado son prácticamente nulos y sólo se han limitado a breves descripciones de las pocas especies que habitan en zonas de montaña $(4,5,6)$. Para reproducirse, las abejas sin aguijón han desarrollado un comportamiento sistemático denominado proceso de aprovisionamiento y oviposición (POP por sus siglas en inglés), en donde las obreras aprovisionan las celdas con alimento larval, la reina deposita el huevo y luego sucede el operculado. En este proceso, al terminar el aprovisionamiento, es muy usual que las abejas obreras depositen huevos que son utilizados por la reina como parte de su alimentación, los cuales son denominados huevos tróficos $(1,3,7)$. Sin embargo, las obreras también pueden ser capaces de ovipositar huevos que no son consumidos por la reina, y que se desarrollan de manera normal dando origen a machos viables. Esta actividad de postura de obreras reproductivas se ha descubierto mediante la videograbación y el análisis visual de los POPs $(8,9,10)$. En este proceso, se ha observado a obreras removiendo los huevos provenientes de la reina para depositar los suyos propios, provocando con esto conflictos entre castas, que llegan a desencadenar épocas de dominancia temporal de las obreras sobre la reina(11,12).

La postura de huevos reproductivos por parte de las obreras también puede suceder antes de la postura de la reina, en donde se ha observado que las obreras presentan una oposición y resistencia a la reina, sellando rápidamente la celda después de poner sus huevos, o incluso las obreras pueden ovipositar en la misma celda junto a los huevos depositados por la reina, en donde la larva proveniente de la obrera puede eliminar a la larva proveniente de la reina $(9,13)$. Además de la detección de obreras reproductivas mediante la videograbación, la presencia de éstas se puede inferir de manera indirecta al determinar la proporción y distribución de los
In general, the knowledge of the biology of stingless bees in the tropics has been studied $(1,2,3)$. However, studies on the biology of meliponines in temperate climate are practically null and only have been limited to brief descriptions of the few species that live in mountain areas $(4,5,6)$. To reproduce, stingless bees have developed a systematic behavior called provisioning and oviposition process (POP), where the workers provide the cells with larval food, the queen lays the eggs and then the cells are sealed. In this process, it is very common at the end of the provisioning, that the worker bees deposit eggs that are used by the queen as part of their diet, which are referred to as trophic eggs $(1,3,7)$. However, the workers may also be able to oviposit eggs that are not consumed by the queen, and developed normally, giving rise to viable males. This reproductive workers activity has been discovered by videotaping and visual analysis of the $\operatorname{POPs}(8,9,10)$. In this process, it has been observed workers removing queen's eggs to lay their own, causing this conflict between castes, which trigger periods of temporary dominance of the workers over the queen $(11,12)$.

The oviposition of reproductive eggs by workers can also happen before of the queen's lay. It was observed that the workers have an opposition and resistance to the queen, quickly sealing the cell after laying their eggs; or even the workers may oviposit in the same cell with the eggs laid by the queen where the larvae's worker can remove larvae of the queen $(9,13)$. In addition to detection of reproductive workers through videotaping, their presence can be inferred indirectly determining the proportion and spatial distribution of individuals in brood combs, since evidence support that when there is activity of reproductive labor, this is reflected in the formation of clusters of males, as the oviposition of the workers can happen together in short periods $(14,15,16)$.

The behaviors mentioned have been studied in species that are distributed in tropical climate and there are no reports on stingless bees of 
individuos en los panales de cría, ya que hay evidencias de que cuando hay actividad de obreras reproductivas, ésta se refleja en la formación de aglomeraciones de machos, debido a que la postura de las obreras puede suceder de manera conjunta en cortos periodos $(14,15,16)$.

Los comportamientos mencionados han sido estudiados en especies que se distribuyen en clima tropical y hasta la fecha no hay reportes en abejas sin aguijón de clima templado, por lo que es interesante determinar en $M$. colimana la posible participación de las obreras en la producción de machos, mediante la observación directa de los POPs y el análisis de la distribución y proporción de los individuos en los panales de cría. La obtención de estos datos permitirá realizar una comparación con las especies tropicales, y determinar otros que pueden ser útiles para ampliar el conocimiento de la biología particular de la especie.

Las observaciones se llevaron a cabo durante la temporada otoñal en los meses de octubre y noviembre del año 2012 en el laboratorio de usos múltiples del Centro Universitario del Sur de la Universidad de Guadalajara (CUSUR), con sede en Ciudad Guzmán, Municipio de Zapotlán el Grande, Jalisco (Figura 1) a una altitud de 1,507 msnm con una temperatura anual promedio de los últimos 10 años de $20.6{ }^{\circ} \mathrm{C}$, máxima de $26.6{ }^{\circ} \mathrm{C}$ y mínima de $11.24{ }^{\circ} \mathrm{C}$, llegándose a presentar hasta 40 días con temperaturas inferiores a los $10^{\circ} \mathrm{C}(17)$. De acuerdo a lo observado en varios años, en esta temporada es cuando está finalizando la temporada de lluvias y es cuando se presenta la floración mayor de plantas de ciclo anual, que pueden aprovechar las abejas.

Para analizar la posible participación de las obreras en la producción de machos se videograbaron durante seis días consecutivos los POPs en cuatro colonias que estuvieron alojadas en cajas de madera y colocadas dentro de un cuarto oscuro con luz roja. Estas colonias se conectaron al exterior con una manguera de plástico para permitir la actividad normal de temperate climate so far. It is interesting to determine the possible participation of the workers of $M$. colimana in the production of males, through direct observation of the POPs and the analysis of the spatial distribution and proportion of individuals in the brood combs. These data will allow to make a comparison with the tropical species, and to determine others that may be useful to expand the knowledge of the particular biology of the species.

The observations were carried out during the autumn in October and November of 2012, in the laboratory of multiple uses of the Universitary Center of the South of the University of Guadalajara (CUSUR), in Ciudad Guzmán, municipality of Zapotlán el Grande, Jalisco (Figure 1) at 1,507 masl, annual average temperature from the last $10 \mathrm{yr}$ of $12.8{ }^{\circ} \mathrm{C}$, maximum of $16.5^{\circ} \mathrm{C}$ and minimum of $11^{\circ} \mathrm{C}$, reaching up to $40 \mathrm{~d}$ with temperatures below $10{ }^{\circ} \mathrm{C}(17)$. According to what was observed in several years, this season is when rains are ending and occurs when annual cycle plants are flowering, for advantage of the bees.

Figura 1. Ubicación del lugar de realización de las observaciones. CUSUR-U de G. Ciudad Guzmán, Jalisco. México

Figure 1. Geographic localization of the trial. University of Guadalajara. Ciudad Guzmán, Jalisco. México

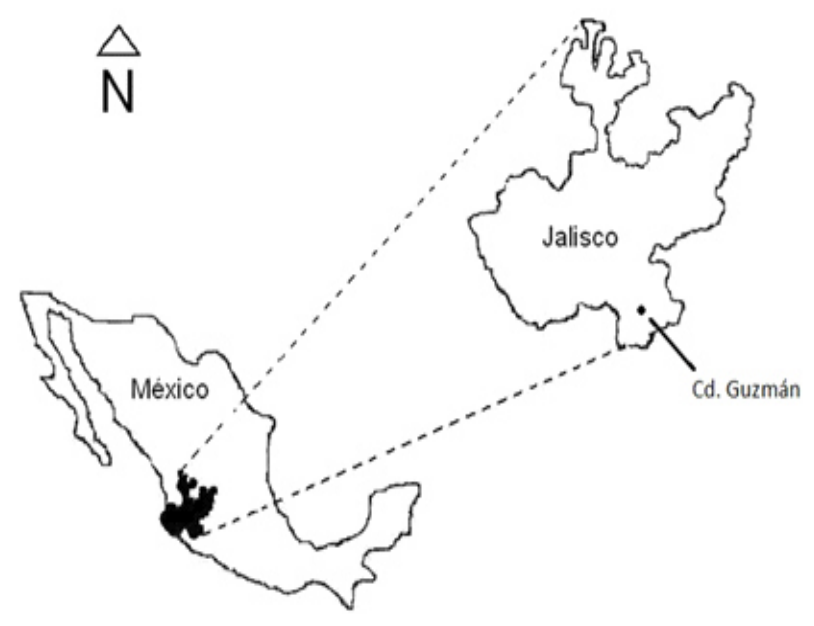


pecoreo. Para poder videograbar la actividad se colocó un cristal transparente en la parte superior de las cajas, en donde se posicionó una cámara de video de $8 \mathrm{~mm}$ en modo de visión nocturna (Sony handycam CCD-118). Posteriormente se analizaron los videos para observar si las obreras exhibieron alguna evidencia de postura de huevos reproductivos, ya sea que se haya observado la postura de ellas después de la postura de la reina, o que hayan eliminado los huevos provenientes de la reina para ovipositar los suyos propios.

Para determinar la proporción relativa de machos, obreras y reinas producidas a un tiempo, y su distribución en los panales de cría, se utilizaron seis colonias de $M$. colimana seleccionadas al azar. De cada una de estas colonias se extrajo un panal de cría a punto de emerger y se colocó en una incubadora (Felisa F-100) a una temperatura a $25{ }^{\circ} \mathrm{C}$ y a $65.5 \%$ de humedad relativa, que son los datos del interior de las colonias que se han registrado en su lugar de origen(18). De cada panal se tomó una fotografía digital, la cual se imprimió y se dividió en tres áreas circulares: centro, la parte media y la periferia, cuidando que el número de celdas fuera similar en las tres partes(14). En estos panales de cría se estuvo verificando la emergencia de los individuos cada tres horas, registrando su sexo, la casta y la posición de las celdas en las que emergieron. Para determinar si hubo aglomeraciones de machos se analizaron las fotografías de forma visual y para hacer la comparación estadística de la distribución de los tres tipos de individuos se realizó un ANOVA(19).

Se analizaron en total 261 POPs. En estos, se pudo observar que las obreras fueron capaces de poner huevos en cerca del $50 \%$ de las celdas, los cuales fueron consumidos por la reina, por lo que se concluyó que funcionaron como huevos tróficos. En un bajo porcentaje (2 \% de todos los POPs) se observó la doble postura de huevos provenientes de obreras, pero en todos los casos la reina procedió a consumirlos. En ningún POP se observó a las
To analyze the possible participation of the workers in the production of males, video film was carried out for six consecutive days of the POPs in four colonies that were housed in wooden boxes and placed in a dark room with red light. These colonies were connected to the outside with a plastic hose to allow the normal activity of bee foraging. To be able to film the activity, a transparent crystal was placed at the top of the boxes, with an $8 \mathrm{~mm}$ video camera in night vision mode (Sony handycam CCD118). Later, videos were analyzed to see if workers exhibited some evidence of reproductive eggs posture, whether that oviposition was after the queen's oviposition has been observed or that they have been removed for the queen to oviposit their own eggs.

Six randomly selected colonies of $M$. colimana were used to determine the relative proportion of males, workers and gynes produced at the same time, and their distribution in the brood combs. From each of these colonies a brood comb about to emerge was extracted and was placed in an incubator (Felisa F-100) at $25^{\circ} \mathrm{C}$ and $65.5 \%$ of relative humidity, which is the data from the interior of the colonies that have been registered in its place of origin(18). A digital photograph was taken from each brood comb, printed and divided into three circular areas: center, middle part and the periphery, taking care that the number of cells was similar in the three sections(14). In these brood combs the emergence of individuals was verified every $3 \mathrm{~h}$, recording their sex, caste and the position of cells in which they emerged. To determine if there were clusters of males the photographs were visually analyzed and ANOVA was performed to make the statistical comparison of the distribution of the three types of individuals(19).

A total of 261 POPs were examined. The workers were able to lay eggs in about $50 \%$ of the cells, which were consumed by the queen, so it was concluded that they functioned as trophic eggs. The double oviposition of eggs from workers was observed in a small percentage 
obreras colocar huevos después de la postura de la reina o junto a los de la reina, y tampoco se observó que las obreras eliminaran los huevos provenientes de la reina para ovipositar los propios.

En total se sexaron 1,120 individuos, de los cuales se encontró que el $22.46 \%$ fueron machos, el $65.98 \%$ fueron obreras y el $11.52 \%$ resultaron reinas vírgenes. En la sección central se registraron $27.49 \%$ machos, $61.3 \%$ de obreras y $11.26 \%$ reinas. En la parte media $23.29 \%$ machos, $65.8 \%$ obreras y $10.96 \%$ reinas. En la periferia de los panales se censaron $19.94 \%$ machos, $70.98 \%$ obreras y $11.08 \%$ reinas.

Además de que visualmente no se detectaron aglomeraciones de machos, el número promedio de estos en las tres secciones no presentaron diferencias significativas ( $F=1.08, G L=2,15$, $P>0.05)$. En relación a la cantidad de obreras y reinas que emergieron de las celdas en las tres áreas tampoco hubo diferencias significativas: obreras $(\mathrm{F}=0.18, \mathrm{GL}=2,15$, $P>0.05)$, reinas $(F=0.02, G L=2,15, P>0.05)$. Los datos promedio y las desviaciones estándar se pueden observar en el Cuadro 1.

Los resultados obtenidos en el presente trabajo nos muestran que no hay evidencias de actividad reproductiva por parte de las obreras, lo que nos permite sugerir que bajo estas condiciones y en esta temporada del año, todos los huevos reproductivos fueron ovipositados por la reina.
( $2 \%$ of all POPs), but in all cases the queen proceeded to consume them. In any POP was observed workers lay eggs after the queen or along queen's oviposition, and nor was that workers eliminated eggs from the queen to oviposit their own.

A total of 1,120 individuals was sexed, and it was found that the $22.46 \%$ were males, $65.98 \%$ were workers and $11.52 \%$ were gynes. In the central section $27.49 \%$ were males, $61.3 \%$ workers and $11.26 \%$ gynes. In the middle part $23.29 \%$ males, $65.8 \%$ workers and $10.96 \%$ gynes. On the periphery of the combs surveyed $19.94 \%$ males, $70.98 \%$ workers and $11.08 \%$ gynes.

In addition, visually clusters of males were not detected; the average number of these in the three sections did not show significant differences ( $F=1.08, D F=2,15, P>0.05)$. There was not also significant differences in relation to the number of workers and gynes who emerged from the cells in the three areas: workers ( $\mathrm{F}=0.18, \mathrm{GL}=2,15, P>0.05)$, gynes $(F=0.02, D F=2,15, P>0.05)$. The average data and the standard deviations can be observed in Table 1.

The results obtained in this study show that there is no evidence of reproductive activity by the workers, thus enabling us to suggest that under these conditions and in this season of the year all the reproductive eggs were laid by the queen. This evidence allows us to infer that

Cuadro 1. Número promedio $( \pm D E)$ de machos, obreras y reinas vírgenes en las secciones centro, medio y periferia de los panales

Table 1. Average number $( \pm S D)$ of males, workers and virgin gynes in different areas of the comb

\begin{tabular}{lccc}
\hline Comb section & Males & Workers & Gynes \\
\hline Central & $17.50 \pm 9.20$ & $39.00 \pm 18.31$ & $7.16 \pm 4.07$ \\
Middle & $14.16 \pm 3.92$ & $40.00 \pm 20.56$ & $6.66 \pm 3.82$ \\
Periphery & $11.33 \pm 7.68$ & $44.83 \pm 14.40$ & $7.00 \pm 5.21$ \\
\hline$(P>0.05)$. & & &
\end{tabular}


Estas evidencias nos permiten inferir que en $M$. colimana la participación de las hembras en la producción de machos está restringida sólo para las reinas. Primeramente, en el análisis de los videos no se observaron evidencias de postura de huevos reproductivos por las obreras, siendo esta observación visual el primer paso para detectar esta posible actividad $(10,15,20)$. Posteriormente, el hecho de que no se observaron aglomeraciones de machos en los panales de cría, puede ser otra evidencia para sugerir que en $M$. colimana no existe actividad reproductiva de las obreras. En diversos trabajos se ha determinado que las aglomeraciones de machos en los panales de cría están relacionados con la presencia de obreras reproductivas, esto tomando en cuenta que estas aglomeraciones son resultado de la actividad de postura que varias obreras realizan de manera conjunta en cortos periodos $(9,14,15)$. En este sentido, el hecho de que en una colonia existan obreras reproductivas puede estar regulado por la relación familiar de los hijos de la reina con los posibles hijos de las obreras(12,21). Debido a que generalmente las reinas de las abejas sin aguijón se aparean con un solo macho, las obreras hijas son hermanas completas, por lo que están más estrechamente relacionadas con los hijos de sus hermanas (sobrinos machos) que con sus hermanos (machos hijos de la reina), favoreciendo con esto la descendencia de sus hermanas y de los suyos mismos; provocando con esto una competencia con la reina por el origen de los machos $(11,12,22)$.

Respecto a los porcentajes de individuos sexuados (el $22.46 \%$ fueron machos y el $11.52 \%$ resultaron reinas vírgenes), estos presentaron diferencias respecto a los datos que se han reportado en otras especies tropicales como $M$. favosa, $M$. trinitatis, $M$. asilvai, M. bicolor, $M$. subnitida y $M$. rufiventris, en donde el porcentaje de machos y reinas son más bajos que en $M$. colimana $(20,23,24)$. De la misma manera, en estudios recientes(25), se reporta para $M$. bicolor una producción de machos de $4.7 \%$, que al compararlo con los in M. colimana the participation of females in the production of males is restricted only to queens. First of all, in the analysis of the videos, there was no evidence of the oviposition of reproductive eggs by the workers, this being the first step to infer the presence of workers with capacity of lay reproductive eggs $(10,15,20)$. Secondarily, the fact that there were no clusters of males in brood combs, may be other evidence to suggest that there is not reproductive activity of the workers in M. colimana. Several works found that clusters of males in brood combs are associated with the presence of reproductive workers, this taking into account that these clusters are a result of the laying activity that several workers made joint in short periods $(9,14,15)$. In this sense, the fact that there are reproductive workers in a colony can be regulated by the family relationship of the offspring of the queen with the possible offspring of the workers $(12,21)$.

As the queens of the stingless bees usually mate with a single male, female workers are full sisters, so they are more closely related to the offspring of her sisters (nephews males) who with his brothers (male offspring of the queen). This, favors the offspring of her sisters and theirs, causing a competition with the queen by the origin of the males $(11,12,22)$.

Regarding the percentages of sexual individuals (22.46\% were males and $11.52 \%$ were virgin gynes), these differences compared to the data reported in other tropical species such as $M$. favosa, M. trinitatis, M. asilvai, M. bicolor, $M$. subnitida and $M$. rufiventris, indicate that the percentage of males and queens are lower than in $M$. colimana $(20,23,24)$. Similarly, recent studies(25), reports from $M$. bicolor a production of $4.7 \%$ males, four times less in this species than in M. colimana. In this sense, Velthuis(26) mentions that males play a vital role in the stingless bees reproduction, and that its presence can ensure the fertilization of the queens in the natural process of swarming, so these differences found in the number of sexed individuals who are related to the reproduction, 
porcentajes obtenidos en $M$. colimana se observa una producción de machos cuatro veces mayor en esta especie de clima templado. En este sentido, Velthuis(26) menciona que los machos juegan un rol vital en la reproducción de las abejas sin aguijón, y que la presencia de estos puede garantizar la fecundación de las reinas en el proceso natural de enjambrazón, por lo que estas diferencias encontradas en la cantidad de individuos sexuados que están relacionados con la reproducción podría ser una estrategia de $M$. colimana para garantizar la supervivencia y reproducción de la especie en climas templados, ya que la presencia de una mayor cantidad de machos y reinas vírgenes podría garantizar la presencia y la fecundación de una nueva reina en el proceso de formación de una nueva colonia $(27,28)$. Otra situación que también podría explicar estas diferencias sería la influencia de los factores ambientales y la disponibilidad de recursos con la presencia de los individuos sexuados en las colonias.

Esta alta producción de individuos reproductivos encontrados en $M$. colimana, puede ser consecuencia de que el momento de las observaciones haya coincidido con las temporadas de floración, y mayor flujo de alimento a la colonia. Se ha reportado que la producción de individuos reproductivos está directamente relacionado con los factores ambientales que impactan en la disponibilidad de recursos y en la cantidad de alimento almacenado en la colonia; de tal manera que se han encontrado más individuos sexuados en las colonias con más recursos alimenticios $(29,30)$, y se ha observado una disminución de los mismos en las temporadas con más precipitación pluvial(31).

De acuerdo a los resultados observados, se sugiere que en las colonias de $M$. colimana no hay participación de las obreras en la producción de machos, y que la producción de individuos sexuados es más alta que otras especies de abejas sin aguijón del mismo género. Sin embargo, a pesar de que en este trabajo se tienen evidencias visuales y poblacionales de might be a strategy of $M$. colimana to ensure the survival and reproduction of the species in temperate climates, as the presence of a greater number of males and virgin queens could guarantee the presence and the fertilization of a new queen in the process of formation of a new colony $(27,28)$. Another situation that might also explain these differences would be the influence of environmental factors and the availability of resources with the presence of sexual individuals in the colonies.

This high production of reproductive individuals found in $M$. colimana, may be due to the fact that the time of observations coincided with the flowering seasons, and a greater flow of food to the colony. The production of reproductive individuals is directly related to the environmental factors, that have an impact on the availability of resources and the amount of food stored in the colony. More sexed individuals in colonies have been found with more feed resources $(29,30)$, and a decrease in the seasons with more rainfall(31).

According to the observed results, it is suggested that in colonies of $M$. colimana there is no participation of the workers in the production of males, and that the production of sexed individuals is higher than other species of the same stingless bees' genus. However, while in this work are visual and population-based evidence that males emerge from the queen, it would be interesting to determine family relationships using methods more comprehensive such as the use of molecular analyses $(32,33)$, to confirm the non-participation of the workers in the production of males in this species.

\section{ACKNOWLEDGMENTS}

Especially to A.F.S. The CONACYT and the PROMEP by the grant for realization of the doctoral program in agricultural sciences in the Universidad Autónoma de Yucatán. At the Center 
que los machos provienen de la reina, sería interesante determinar las relaciones familiares mediante métodos más exhaustivos como son el uso de análisis moleculares $(32,33)$, con lo que se podría confirmar en esta especie, la no participación de las obreras en la producción de machos.

\section{AGRADECIMIENTOS}

Especialmente para A.F.S. Al CONACYT y al PROMEP por la beca para la realización del Doctorado en Ciencias Agropecuarias en la Universidad Autónoma de Yucatán. Al Centro Universitario del Sur de la Universidad de Guadalajara por facilitar sus instalaciones para la realización de los experimentos.

\section{LITERATURA CITADA}

1. Sakagami SF. Stingless bees. In: Herman HR editor. Social Insects. London, U.K: Academic Press; 1982:36-423.

2. Nogueira-Neto P. Vida e criacao de abelhas indígenas sem ferrão. Sao Paulo, Brasil: Editora Nogueirapis; 1997.

3. Quezada-Euan JJG. Biología y uso de las abejas sin aguijón de la península de Yucatán, México (Hymenoptera: Meliponini). Yucatán, México: Ediciones de la Universidad Autónoma de Yucatán; 2005.

4. Melo ARG. Notes on the nesting biology of Melipona capixaba (Hymenoptera, Apidae). Jour Kan Entomol Soc 1996;(2):207210.

5. Ayala R. Revisión de las abejas sin Aguijón de México (Hymenoptera: Apidae: Meliponini). Fol Entom Mex 1999;(106):1-123.

6. Nates-Parra G. Las abejas sin aguijón (Hymenoptera:Apidae:Meliponini) de Colombia. Bio Col $2001 ;(2): 233-248$.

7. Wille A. Biology of stingless bees. Ann Rev Ent 1983;(28):4246.

8. Bego LR. On social regulation in Nannotrigona (Scaptotrigona) postica Latreille, with special reference to productivity of colonies (Hymenoptera, Apidae, Meliponinae). Rev Bras Entom 1990;(34):721-738.

9. Koedam D. Productions of queens, workers and males in the stingless bee Melipona favosa (Apidae: Meliponinae): Patterns in time and space. Neth Jour Zool 1999;(49):289302.

10. Sommeijer MJ, Chinh TX, Meeuwsen FJAJ. Behavioural data on the production of males by workers in the Stingless bee Melipona favosa (Apidae: Meliponinae). Insec Soc 1999;(46):92-93.
Universitary of the South of the University of Guadalajara for providing their facilities for conducting the experiments.

End of english version

11. Crespi BJ. Cannibalism and trophic eggs in subsocial and eusocial insects. In: Elgar MA, Crespi BJ editors. Cannibalism: and evolutionary approach to castes and reproduction. Oxford: Oxford University Press; 1992:176-213.

12. Peters JM, Queller DC, Imperatriz-Fonseca VL, Roubik DW, Strassmann JE. Mate number, kin selection and social conflicts in stingless bees and honey bees. Proc R Soc Lond 1999;(266):379-384.

13. Beig $D$. The production of males in queenright colonies of Trigona (Scaptotrigona postica). J Apic Res 1972;(11):3339.

14. Koedam D, Contrera FA, Imperatriz-Fonseca VL. Clustered male production by workers in the stingless bee Melipona subnitida Ducke (Apidae:Meliponinae). Insec Soc 1999;(46):387-391.

15. Chinh XT, Grob BJG, Meeuwsen JAJF, Sommeijer MJ. Patterns of male production in the stingless bee Melipona favosa (Apidae: Meliponini). Apidol 2003;(34):161-170.

16. Moo-Valle H, Quezada-Euán JJG, Canto-Marin J, GonzalezAcereto JA. Caste ontogeny and the distribution of reproductive cells on the combs of Melipona beecheii (Apidae: Meliponini). Apidol 2004;(35):587-594.

17. CONAGUA Archivos zona sur de Jalisco. Observatorio metereologico regional. Comision Nacional del Agua. Cd. Guzmán, Mpio de Zapotlán el Grande, Jalisco, México. 2012.

18. Macias-Macias MJO, Quezada-Euan JJG, Gonzalez TJM. Effect of lodging type on the internal temperature and humidity of colonies of Melipona colimana (Hymenoptera:Meliponini) from a Mexican temperate zone. J Apic Res 2011;(50):235-241.

19. Zar J. Biostatistic analisis. New York,USA: Prentice Hall; 1999.

20. Sommeijer MJ, de Bruijn LLM, Meeuwsen FJAJ, Martens EP. Natural patterns of caste and sex allocation in the stingless bees Melipona favosa and M. trinitatis related to worker behavior. Insec Soc 2003;(50)38-44.

21. Palmer KA, Oldroyd BP, Quezada-Euán JJG, Paxton RJ, MayItza $W$ de J. Paternity frequency and maternity of males in some stingless bee species. Mol Ecol 2002;(11):2107-2113.

22. Toth $E$, Queller CD, Imperatriz-Fonseca VL, Strassmann EJ. Genetic and behavioral conflict over male production between workers and queens in the stingless bee Paratrigona subnuda. Beha. Ecol Soc 2002;(53):1-8.

23. Santos-Filho PS, Alves DA, Eterovic A, Imperatriz-Fonseca $\mathrm{VL}$, Kleinert PAM. Numerical Investment in sex and caste by stingless bees (Apidae: Meliponini): a comparative analysis. Apidol 2006;(37):207-221.

24. Alves DA, Imperatriz-Fonseca VL, Nogueira-Neto P, SantosFilho PS. Rainhas e machos produzidos em uma população de abelha sem ferrão (Melípona rufiventris rufiventris, Apidae: Meliponini), Anais do VII Congresso de Ecologia do Brasil Caxambu, Brasil. 2007. 


\section{EMERGENCIA Y DISTRIBUCIÓN DE Melipona colimana EN CLIMA TEMPLADO}

25. Ferreira JNT, Blochtein B, Serrao JO. Seasonal production and spatial distribution of Melipona bicolor schencki (Apidae: Meliponini) castes in brood combs in Southern Brazil. Apidol 2013;(44):176-187.

26. Velthuis HHW, Koedam D, Imperatriz-Fonseca VL. The males of Melipona and others stingless bees, and their mothers. Apidol 2005;(36):169-185.

27. González-Acereto JA, De Araujo-Freitas Ch. Manual de Meliponicultura Mexicana F.M.V.Z. Fundación Produce Guerrero A.C. Universidad Autónoma de Yucatán. Yucatán 2005.

28. Gonzalez-Acereto JA. Cría y manejo de abejas nativas sin aguijón en México. Universidad Autónoma de Yucatán. Secretaria de Fomento Agropecuario y Pesquero. Fundación Produce Yucatán. Yucatán. 2008.

29. Chinh XT, Sommeijer MJ. Production of sexuals in the stingless bee Trigona (Lepidotrigona) ventralis flavibasis
Cockerell (Apidae,Meliponini) in northern Vietnam. Apidol 2005;(36):493-503.

30. Moo-Valle H, Quezada-Euán JJG, Wenseleers T. The effect of food reserves on the production of sexual offspring in the stingless bee Melipona beecheii (Apidae: Meliponini). Ins Soc 2001;(48):1-6.

31. Brito DV; Nunes SRA, Pequeno CLPA, Nunez-Silva CG, Carlvalho-Zilse GA. Differential environmental effects on caste allocation in two Amazonian Melipona bees. Apidol 2013;(44):666-627.

32. Paxton JR. Genetic structure of colonies and a male aggregation in the stingless bee Scaptotrigona postica, as revealed by microsatellite analysis. Insect Soc 2000;(47):63-69.

33. Moritz AFR, Scharpenberg MH, Lattorff GMH, Neumann P. A tecnical note for using microsatellite DNA analyses in haploid male DNA pools of social Hymenoptera. Insect Soc 2003;(50):398-400. 
